\title{
HUBUNGAN PENGETAHUAN, SIKAP, PERSONAL HYGIENE TERHADAP PENYAKIT HEPATITIS-A DI KABUPATEN PACITAN 2019
}

The Relationship Of Knowledge, Attitude, Personal Hygiene On Hepatitis-A Disease In Pacitan 2019

\author{
Mufiadzatul Ardiyah ${ }^{1}$, Nurhaidah ${ }^{2}$, Ferry Kriswandana ${ }^{3}$ \\ ${ }^{1}$ Poltekkes Kemenkes Surabaya \\ ${ }^{2}$ Poltekkes Kemenkes Makassar \\ ${ }^{3}$ Poltekkes Kemenkes Surabaya \\ *) mufiadzatulardiyah@gmail.com (081259208583) / ( 081357502320) \\ ${ }^{* *}$ nurhaidah2@gmail.com (081357502320)
}

\begin{abstract}
Hepatitis $A$ is an inflammation of the liver caused by the hepatitis $A$ virus. This disease can generally cause an outbreak In June 2019 the government established the status of hepatitis $A$ outbreaks in Pacitan Regency, which is spread across several districts. Based on data from the Pacitan District Health Office, there were 1310 people with hepatitis $A$ as of October 2019. The purpose of this study was to determine the relationship of knowledge, attitudes, and personal hygiene to the incidence of hepatitis $A$ in the working area of Ngadirojo Puskesmas Pacitan Regency. The type of research used to conduct this research is quantitative research with observational analytic methods and uses a case control research design. The population in this study were 280 people and the total sample was 60 people with case details of 30 people and control of 30 people. Case and control sampling is done by simple random sampling. Data collection by interview, then the data analyzed analytically using the Chi Square test and Contingency Coefficient. The results of this study show a significant relationship between the level of knowledge with the incidence of Hepatitis $A$ ( $p$ value $=0.002 ; C=0.374$; $O R=5.675,95 \% \mathrm{Cl}: 1.841$-17.494), attitudes with Hepatitis $A$ ( $p$ value $=0.004 ; C=0.346 ; O R=4.75,95 \% C l: 1.584$ 14.245), and personal hygiene with the incidence of Hepatitis $A$ (pvalue $=0.001 ; C=0.407 ; O R=7.5,95 \% C l: 2.244$ 25.062). Researchers suggest giving the active role of health workers and the community also to prevent the Hepatitis $A$ outbreaks, giving the primery protectionaction in the form of Hepatitis A immunization as a preventive effort, implementing Clean and Healthy Behavior, and monitoring activities of post-KLB evaluation so that no outbreaks are expected. $A$ in Pacitan Regency.

Keywords : Hepatitis A, Personal Hygiene, Outbreak
\end{abstract}

\section{ABSTRAK}

Hepatitis A adalah penyakit radang hati yang disebabkan oleh virus hepatitis A. Penyakit ini umumnya dapat menyebabkan wabah. Pada tahun 2019 Bulan Juni pemerintah menetapkan status KLB hepatitis A di Kabupaten Pacitan yang tersebar di beberapa kecamatan. Berdasarkan data Dinas Kesehatan Kabupaten Pacitan, penderita hepatitis A per Bulan Oktober 2019 sebanyak 1.310 orang. Tujuan dari penelitian ini adalah untuk mengetahui hubungan pengetahuan, sikap, dan personal hygiene terhadap kejadian hepatitis A di Wilayah Kerja Puskesmas Ngadirojo Kabupaten Pacitan. Jenis penelitian yang digunakan untuk melakukan penelitian ini adalah penelitian kuantitatif dengan metode analitik observasional danmenggunakan desain penelitian case control. Populasi dalam penelitian ini sebanyak 280 orang dan jumlah total sampel sebanyak 60 orang dengan rincian case sebanyak 30 orang dan controlsebanyak 30 orang. Pengambilan sampel case dan controldilakukan dengan cara simple random sampling.Pengumpulan data dengan cara wawancara, kemudian data yang diperoleh selanjutnya dianalisis secara analitik menggunakan uji Chi Square dan Contingency Coefficient. Hasil penelitian ini menunjukkan hubungan yang signifikan antara tingkat pengetahuan dengan kejadian Hepatitis A (pvalue $=0,002 ; \mathrm{C}=0,374 ; \mathrm{OR}=5,675,95 \% \mathrm{Cl}: 1,841-17,494$ ), sikap dengan dengan Hepatitis $\mathrm{A}$ (pvalue $=0,004 ; \mathrm{C}=0,346 ; \mathrm{OR}=4,75,95 \% \mathrm{Cl}: 1,584-14,245)$, dan personal hygiene dengan kejadian Hepatitis $\mathrm{A}$ (pvalue= $0,001 ; \mathrm{C}=0,407 ; \mathrm{OR}=7,5,95 \% \mathrm{Cl}: 2,244-25,062)$. Peneliti menyarankan peran aktif tenaga kesehatan dan masyarakat dalam upaya penanggulangan dan pencegahan KLB Hepatitis A, melakukantindakan primery protection berupa imunisasi Hepatitis A sebagai upaya preventif, menerapkan Perilaku Hidup Bersih dan Sehat, dan kegiatan monitoring evaluasi pasca KLB sehingga diharapkan tidak terjadi kembaliKLB Hepatitis A di Kabupaten Pacitan

Kata kunci : Hepatitis A, Personal Hygiene, Kejadian Luar Biasa

\section{PENDAHULUAN}

Penyakit

hepatitis merupakan

masalah kesehatan masyarakat yang terdiri dari Hepatitis A, B, C, D, dan E. Hepatitis A dan $E$ sering muncul sebagai Kejadian Luar Biasa (KLB) di belahan dunia termasuk di Indonesia. Hepatitis A disebabkan karena agent penyakit berupa Virus Hepatitis A (HAV) yang ditularkan melalui fecal oral (makanan dan minuman) dan biasanya berhubungan dengan perilaku hidup bersih dan sehat (PHBS), dapat sembuh dengan baik namun seringkali muncul tanpa adanya gejala, dan penyakit yang bersifat akut(drg. Oscar Primadi, 2014).Di Indonesia, Hepatitis A muncul dalam Kejadian Luar Biasa (KLB). Dari tahun ke tahun kejadian luar biasa Hepatitis A selalu meningkat. Pada tahun 2018 terjadi Kejadian Luar Biasa (KLB) Hepatitis A sebanyak 9 kali yang tersebar di 5 Provinsi, dan 8 Kabupaten/ Kota dengan jumlah kasus sebanyak 564 kasus dengan angka kematian 0 dan CFR sebesar $0 \%$ (Kemenkes, 2018). Berdasarkan data penyakit Hepatitis A dari Dinas Kesehatan Kabupaten Pacitan Tahun 2019, KLB Hepatitis A dengan 
jumlah kasus penderita Hepatitis A yang sudah tercatat per 31 di Kabupaten Pacitan. Penetapan lokasi penelitian berada di Kecamatan Ngadirojo karena terdapat 7 kasus baru setelah masa kedua KLB per Oktober 2019 di Kecamatan Ngadirojo.Hepatitis A merupakan penyakit yang dapat sembuh dengan sendirinya tetapi dapat menimbulkan dampak epidemiologis dan klinis. Infeksi HAV di Indonesia banyak mengenai anak usia $<5$ tahun dan biasanya tanpa gejala.

Anak-anak merupakan sumber penularan bagi orang dewasa di sekitarnya dengan risiko kematian dan kesakitan yang lebih berat seperti dapat menimbulkan masalah pada usia produktif walaupun penyakit ini bukan merupakan penyebab kematian langsung (Masriadi, 2017). Bakteri yang menyebabkan penyakit Hepatitis A adalah Virus Hepatitis A (HAV). Terjadinya penularan penyakit Hepatitis A sangat berhubungan erat dengan kondisi sanitasi lingkungan, higiene dan sanitasi pangan, serta perilaku hidup bersih dan sehat (Kemenkes, 2018). Berdasarkan survei pendahuluan ditemukan 5 penderita memiliki gejala awal hampir sama seperti mual, muntah, tinja encer, urin berwarna gelap seperti air teh, demam, dan 2 dari 5 penderita hingga sudah mengalami fase ikterik yaitu bola mata dan kulit menguning.

Kemudian sumber air bersih menggunakan air sumber berupa mata air pegunungan dan berasal dari tangki sumber air bersih. Sumber air minum yang digunakan oleh penderita Hepatitis-A yaitu menggunakan air minum isi ulang produksi UKM desadan ada juga yang menggunakan air sumur sebagai sumber air minum, namun perilaku tidak pernah memasak airnya terlebih dahulu sebelum dikonsumsi terdapat sebanyak tiga dari lima penderita. Perilaku personal hygiene penderita yang belum menerapkan CTPS dengan baik dan benar sebanyak empat dari lima penderita, perilaku menggunakan alat makan yang sama secara bergantian juga dilakukan oleh penderita, namun terdapat tiga penderita tidak memiliki kebiasaan membeli makanan di warung makan atau pedagang keliling dan tidak mempunyai kebiasaan makan makanan mentah. Terdapat dua penderita anak-anak dengan gejala sama dengan ketiga penderita yang lain, kemudian perilaku anak-anak tersebut yaitu memiliki kebiasaan jajan di kantin sekolah dan tidak melakukan cuci tangan pakai sabun sebelum makan. Tujuan dari penelitian ini untuk mengetahui hubungan antara pengetahuan, sikap, dan personal hygienedengan kejadian penyakit Hepatitis A di Wilayah Kerja Puskesmas Ngadirojo Kabupaten Pacitan.

\section{METODE \\ 1. Metode}

Jenis metode yang digunakan dalam pengumpulan data adalah wawancara, observasi, dan studi pustaka. Instrumen yang dilakukan adalah data rekam medis dari Dinas Kesehatan Kabupaten Pacitan dan Puskesmas Ngadirojo berisi nama dan alamat penderita Hepatitis A serta kuisioner terstruktur.

\section{Desain}

Desain penelitian ini menggunakan desain penelitian kuantitatif dengan metode analitik observasional. Desain penelitian ini adalah case control study.

\section{Waktu}

Penelitian ini dilakukan di Wilayah Kerja Puskesmas Ngadirojo Kabupaten Pacitan pada Bulan Oktober 2019 - Februari 2020. Populasi adalah seluruh warga yang menderita Hepatitis A di seluruh Kabupaten Pacitan. Objek penelitian ini adalah penderita (kasus) dan non penderita (kontrol) penyakit Hepatitis A di Wilayah Kerja Puskesmas Ngadirojo Kabupaten Pacitan dengan perbandingan jumlah kasus dan kontrol 1:1. Teknik pengambilan sampel adalah Simple Random Sampling.

\section{Populasi dan Sampel}

Jumlah Populasi sebanyak 1.310 orang yang merupakan penderita Hepatitis A di Wilayah Kerja Puskesmas Ngadirojo Per Bulan Oktober 2019. Jumlah sampel yang digunakan berjumlah 60 orang dengan perbadingan $1: 1$ antara kasus dan kontrol. Cara pengumpulan subjek menggunakan simple random sampling.

\section{Analisis Data}

Pengolahan data menggunakan penyajian dalam bentuk tabel. Analisis data yang dilakukan adalah menggunakan analisis univariat dan bivariat dengan uji chi square $\left(\mathrm{x}^{2}\right)$ dan contingency coefficient.

\section{HASIL}

Hasil uji pada analisis univarat mendapatkan karakteristik responden berupa jenis kelamin, umur, dan pendidikan Penelitian ini melibatkan 60

responden, yaitu sebanyak 30 kasus dan 30 kontrol. Pada jenis kelamin, responden paling banyak berjenis kelamin perempuan sebanyak 43 orang. Pada kelompok umur, responden 
paling banyak kelompok umur 26 - 45 tahun sebanyak 23 orang. Sedangkan pada pendidikan, responden paling banyak memiliki pendidikan terakhir yaitu pendidikan tinggi (SMA, Perguruan Tinggi) sebanyak 32 orang (Tabel 1). Responden mayoritas memiliki tingkat pengetahuan rendah $(56,7 \%)$, sikap yang negatif $(55,0 \%)$, dan personal hygiene yang kurang baik $(61,7)$ (Tabel 2).

Tabel 1.

Distribusi Frekuensi Karakteristik Responden Di Wilayah Kerja Puskesmas Ngadirojo Kabupaten Pacitan

\begin{tabular}{lcc}
\hline $\begin{array}{c}\text { Karakteristik } \\
\text { Responden }\end{array}$ & Frekuensi & $\begin{array}{c}\text { Persentase } \\
(\%)\end{array}$ \\
\hline $\begin{array}{c}\text { Jenis Kelamin } \\
\text { Laki-laki }\end{array}$ & 17 & 28,3 \\
$\quad$ Perempuan & 43 & 71,7 \\
Umur (tahun) & & \\
$12-25$ & 14 & 23,3 \\
$26-45$ & 23 & 38,3 \\
$46-65$ & 22 & 36,7 \\
$\quad>65$ & 1 & 1,7 \\
Pendidikan & & \\
$\quad$ Tidak tamat, & 28 & 46,7 \\
$\quad$ SD, SMP & 32 & 53,3 \\
$\quad$ SMA, & & \\
$\quad$ Perguruan & & \\
$\quad$ Tinggi & & \\
Sumber : Data Primer, 2020 &
\end{tabular}

Tabel 2.

Distribusi Frekuensi Responden Berdasarkan Tingkat Pengetahuan, Sikap, Dan Personal Hygiene

\begin{tabular}{|c|c|c|c|}
\hline Variabel & Frekuensi & $\begin{array}{c}\text { Persentase } \\
(\%)\end{array}$ & $\begin{array}{l}\text { ada nubungan antara pengetanuan dengan } \\
\text { kejadian Hepatitis A. Hal ini sejenis dengan } \\
\text { penelitian yang dilakukan bahwa tingkat }\end{array}$ \\
\hline $\begin{array}{l}\text { Tingkat } \\
\text { Pengetahuan }\end{array}$ & & & pengetahuan memiliki hubungan dengan \\
\hline Tinggi & 26 & 43,3 & \\
\hline $\begin{array}{l}\text { Rendah } \\
\text { Sikan }\end{array}$ & 34 & 56,7 & Hubungan \\
\hline Sikap & & & Penyakit Hepatitis A \\
\hline Positif & 27 & 45,0 & Hasil analisis hubungan \\
\hline $\begin{array}{l}\text { Negatif } \\
\text { Personal } \\
\text { Hygiene }\end{array}$ & 33 & 55,0 & $\begin{array}{l}\text { dengan kejadian Penyakit Hepatitis A } \\
\text { diperoleh responden dengan sikap positif }\end{array}$ \\
\hline Baik & 23 & 38,3 & sebanyak 8 responden $(26,7 \%)$ pada \\
\hline Kurang Baik & 37 & 61,7 & kelompok kasus, sedangkan sebanyak 19 \\
\hline umber : Data $\mathrm{Pr}$ & r, 2020 & & $\begin{array}{l}\text { responden }(63,3 \%) \text { pada kelompok kontrol. } \\
\text { Responden dengan sikap negatif sebanyak } 22 \\
\text { responden }(73,3 \%) \text { pada kelompok kasus dan } \\
11 \text { responden }(36,7 \%) \text { pada kelompok kontrol. } \\
\text { Hasil uji Chi-Square memperoleh nilai }\end{array}$ \\
\hline
\end{tabular}

\section{PEMBAHASAN}

1. Hubungan Pengetahuan dengan Kejadian Penyakit Hepatitis A

Hasil analisis hubungan antara tingkat pengetahuan dengan kejadian Penyakit Hepatitis A diperoleh responden dengan tingkat pengetahuan tinggi sebanyak 7 responden $(23,3 \%)$ pada kelompok kasus, sedangkan sebanyak 19 responden $(63,3 \%)$ pada kelompok kontrol. Responden dengan tingkat pengetahuan rendah sebanyak 23 responden $(76,6 \%)$ pada kelompok kasus dan 11 responden (36,7\%) pada kelompok kontrol.

Hasil uji Chi-Square memperoleh nilai pvalue $=0,002<\alpha(0,05)$, maka dapat disimpulkan bahwa ada hubungan yang signifikan antara tingkat pengetahuan dengan kejadian Hepatitis A. Berdasarkan hasil uji Contingency Coefficient mendapatkan nilai pvalue $=0,374$ artinya nilai $C \neq 0$. Hal ini menunjukkan terdapat hubungan yang lemah antara tingkat pengetahuan dengan kejadian Hepatitis A. Tingkat pengetahuan dengan nilai Odds Ratio (OR) sebesar 5,675 pada confident interval 1,841-17,494 (Tabel 3).

Berdasarkan tinjauan teoritis bahwa untuk seseorang berperilaku sehat diperlukan pengetahuan yang baik sehingga mempermudah terwujudnya perilaku sehat (Notoatmodjo, 2007).

Menurut penelitian yang dilakukan oleh Aniko Prestia Sakti (2012) menyebutkan bahwa responden dengan pengetahuan rendah berisiko terkena hepatitis $A$ sebanyak 5,96 kali dibandingkan dengan responden yang berpengetahuan tinggi. Kemudian menurut penelitian lain yang dilakukan oleh Dwi Hastuti, Suklan (2012) menyatakan bahwa ada hubungan antara pengetahuan dengan (n) 
pvalue $=0,004<\alpha \quad(0,05)$, maka dapat disimpulkan bahwa ada hubungan yang signifikan antara sikap dengan kejadian Hepatitis A. Berdasarkan hasil uji Contingency Coefficient mendapatkan nilai pvalue $=0,346$ artinya nilai $C \neq 0$. Hal ini menunjukkan terdapat hubungan yang lemah antara sikap dengan kejadian Hepatitis A. Sikap dengan nilai Odds Ratio (OR) sebesar 4,75 pada confident interval 1,584-14,245 (Tabel 3).

Hasil penelitian ini sesuai dengan tinjauan teoritis yang mengatakan bahwa sikap yang positif akan mempermudah terwujudnya perilaku sehat (Notoatmodjo, 2007). Menurut penelitian yang dilakukan oleh Derma Kamsil Ratih (2015) menyebutkan bahwa terdapat hubungan signifikan antara perilaku (pengetahuan, sikap, dan tindakan) masyarakat dengan kejadian Hepatitis A. Faktor adanya hubungan antara pengetahuan, sikap, dan dukungan keluarga dengan perilaku pencegahan Hepatitis A adalah faktor yang risiko yang signifikan dengan kejadian Hepatitis A (Arbi, 2012). Faktor penunjang lainnya adalah faktor lingkungan. Penyakit hepatitis A disebabkan oleh virus yang memiliki reservoir di air. Penyebaran hepatitis A melalui air dan makanan. Parameter lingkungan yang mendukung adanya indikasi keberadaan virus Hepatitis A di air adalah bakteri Eschericia coli. Maka dari itu diperlukan sikap yang dapat mencegah terjadinya penyebaran penyakit Hepatitis A.

\section{Hubungan Personal Hygiene dengan Kejadian Penyakit Hepatitis A}

Hasil analisis hubungan antara personal hygienedengan kejadian Penyakit Hepatitis A diperoleh responden dengan personal hygienebaik sebanyak 5 responden (16,7\%) pada kelompok kasus, sedangkan sebanyak 18 responden $(60,0 \%)$ pada kelompok kontrol. Responden dengan personal hygienekurang baik sebanyak 25 responden (83,3\%) pada kelompok kasus dan 12 responden $(40,0 \%)$ pada kelompok kontrol.

Hasil uji Chi-Square memperoleh nilai pvalue $=0,001<\alpha \quad(0,05)$, maka dapat disimpulkan bahwa ada hubungan antara proporsi personal hygienedengan kejadian
Hepatitis A. Berdasarkan hasil uji Contingency Coefficient mendapatkan nilai pvalue $=0,407$ artinya nilai $C \neq 0$. Hal ini menunjukkan terdapat hubungan yang lemah antara personal hygienedan kejadian Hepatitis A. Personal hygiene dengan nilai Odds Ratio (OR) sebesar 7,5 pada confident interval 2,244 $-25,062$ (Tabel 3).

Hasil penelitian ini sejenis dengan penelitian lain yang menyebutkan bahwa perilaku sehat dan tidak higienis adalah faktor risiko Hepatitis A. Perilaku tersebut meliputi riwayat kontak dengan penderita, tidak mencuci tangan dengan sabun, tidak mencuci alat makan dengan sabun, sering mengonsumsi sayur dan makanan mentah, berperilaku tukar menukar alat makan, sering makan di warung yang hanya mencuci dengan satu ember, dan tidak memperhatikan kebersihan warung mempunyai hubungan yang signifikan dengan Hepatitis A (Rahmah, 2014). Menurut penelitian yang dilakukan oleh Lidya Alvira (2018) menyatakan bahwa faktor risiko berupa personal hygiene dengan kejadian Hepatitis A memiliki nilai risiko sebesar OR 5,84; $95 \% \mathrm{Cl} \quad(2,5 \quad-13,2)$. Contohnya yaitu kegiatan CTPS (Cuci Tangan Pakai Sabun) setelah BAB (Buang Air Besar) dan BAK(Buang Air Kecil) menjadi faktor risiko Hepatitis A dengan OR 7,90.

Teori Lawrence Green (1980) dalam Notoatmodjo (2013), mengatakan bahwa perilaku seseorang ditentukan oleh tiga faktor yaitu faktor predisposisi adalah faktor yang ada dalam diri individu (pengetahuan, budaya, kepercayaan), faktor pemungkin adalah faktor yang memungkinkan terjadinya perilaku (sarana dan prasarana), dan faktor penguat adalah faktor yang memperkuat terjadinya perilaku.Penelitian lain juga menyebutkan bahwa perilaku sehat dan tidak higienis adalah faktor risiko Hepatitis A (Rahmah, 2014). Hubungan yang lemah antara personal hygienedengan kejadian Hepatitis A disebabkan oleh terdapat beberapa faktor lainnya yang lebih berhubungan dengan kejadian Hepatitis A seperti kebutuhan sanitasi yang baik. 
Tabel 3.

Distribusi Analisis Bivariat Di Wilayah Kerja Puskesmas Ngadirojo Kabupaten Pacitan

\begin{tabular}{lccc}
\hline \multicolumn{1}{c}{ Variabel } & OR & $\mathbf{9 5 \%} \mathbf{C l}$ & $\mathbf{p}$ \\
\hline Tingkat & 5.675 & $1.841-$ & 0.002 \\
Pengetahuan & & 17.494 & \\
Sikap & 4,75 & $1,584-$ & 0,004 \\
& & 14,245 & \\
Personal & 7,5 & $2,244-$ & 0,001 \\
Hygiene & & 25,062 & \\
\hline
\end{tabular}

Sumber : Data Primer, 2020

Pada tabel diatas menunjukkan bahwa Hasil analisa pada penelitian ini adalah seseorang yang memiliki tingkat pengetahuan yang rendah memiliki risiko 5,675 kali terkena Hepatitis A dibandingkan seseorang yang memiliki tingkat pengetahuan yang tinggi. Hal ini dikarenakan pengetahuan merupakan cara pertama yang dilakukan dalam perubahan perilaku seseorang, sehingga sebuah perubahan perilaku pada seseorang yang didasari dengan pengetahuan dan rasa ingin tahu maka akan bertahan lebih lama penerapannya dibandingkan dengan yang tidak didasari dengan pengetahuan. Tingkat pengetahuan seseorang dapat dilihat dalam salah satu indikator penilaian yaitu pengetahuan tentang sakit dan penyakit, kemudian pengetahuan ini mencakup kemampuan seseorang memahami suatu penyakit yang dilihat dari penyebab, gejala, cara penularan, dan cara pengobatan suatu penyakit. Maka dari itu tingkat pengetahuan merupakan faktor risiko terjadinya Hepatitis A.

Upaya untuk meningkatkan tingkat pengetahuan adalah melalui penyuluhan kesehatan serta promosi kesehatan tentang pencegahan Hepatitis A kemudian menerima informasinya dan menerapkannya sehingga diharapkan tidak terjadi lagi kasus penyakit Hepatitis A di Kabupaten Pacitan.

Penderita Hepatitis A lebih banyak memiliki sikap yang negatif daripada yang memiliki sikap positif. Hal ini karena responden dengan sikap yang negatif memiliki peluang untuk menjadi sakit lebih besar 4,75 kali dibandingkan dengan responden dengan sikap yang positif.

Berdasarkan hasil penelitian dapat disimpulkan bahwa seseorang yang memiliki personal hygiene yang buruk memiliki risiko 7,5 kali terkena Hepatitis A dibandingkan seseorang dengan personal hygiene yang baik. Hal ini dikarenakan personal hygiene merupakan perubahan perilaku yang dilakukan untuk menimbulkan bentuk perawatan diri agar memiliki penampilan dan memenuhi kebutuhan tubuhnya yang sesuai dengan konsep kesehatan sehingga dapat mencegah terjadinya penyakit menular khususnya Hepatitis A yang sebagian besar memang salah satu praktik pencegahannya adalah menerapkan personal hygiene.

Solusi untuk meningkatkan personal hygiene yang baik adalah dengan membiasakan untuk menjaga kebersihan diri, melatih hidup bersih dan sehat dengan memperbaiki gambaran atau persepsi terhadap kesehatan dan kebersihan, selalu menerapkan cuci tangan pakai sabun dengan benar pada saat 5 kritis, meningkatkan sanitasi, melakukan pengolahan makanan dan minuman dengan benar, kebersihan saat menjamah makanan, serta menciptakan penampilan atau kualitas hidup yang sesuai dengan kebutuhan kesehatan agar terhindar dari beberapa penyakit menular. Perubahan perilaku seseorang terhadap personal hygiene dapat dilihat dari perbandingan personal hygiene sebelum memahami dan menyikap suatu objek dengan setelah memahami dan menyikapi suatu objek tersebut.

\section{KESIMPULAN}

Tingkat Pengetahuan, sikap, dan personal hygiene memiliki hubungan dengan kejadian penyakit Hepatitis A. Ketiga variabel bebas tersebut memiliki hubungan yang lemah dengan variabel terikat. Responden dengan pengetahuan rendah lebih berisiko terhadap Hepatitis A sebesar 5,676 kali daripada responden dengan pengetahuan tinggi (OR : $5,675,95 \% \mathrm{Cl}: 1,841-17,494)$, kemudian responden dengan sikap yang negatif lebih berisiko terhadap Hepatitis A sebesar 4,75 kali daripada responden dengan sikap yang positif $(\mathrm{OR}=4,75,95 \% \mathrm{Cl}: 1,584-14,245)$, dan 
Jurnal Sulolipu : Media Komunikasi Sivitas Akademika dan Masyarakat

Vol. 20 No. 22020

e-issn : 2622-6960, p-issn : 0854-624X

responden dengan personal hygiene yang kurang baik lebih berisiko terhadap Hepatitis $A$ sebesar 7,5 kali daripada responden dengan personal hygiene yang baik $(\mathrm{OR}=7,5,95 \% \mathrm{Cl}$ : $2,244-25,062)$.

\section{SARAN}

Saran yang dapat diberikan bagi Dinas Kesehatan Kabupaten Pacitan adalah Meningkatkan peran aktif tenaga kesehatan dalam memberikan upaya penanggulangan Hepatitis A sejak dini melalui sistem kewaspadaan dini (SKD) KLB dengan cara memberikan penyuluhan kesehatan rutin sebagai upaya promotif, serta upaya preventif yang dapat dilakukan adalah membuat program imunisasi Hepatitis A pada masyarakat sebagai tindakan primery protection. Saran bagi masyarakat adalah menerapkan PHBS dalam kehidupan seharihari dan semakin sadar akan pentingnya upaya pencegahan penyakit menular khususnya Hepatitis A agar dapat memutus rantai penularan dan penyebaran Hepatitis $A$ sehingga tidak terjadi KLB kembali di Kabupaten Pacitan.

\section{DAFTAR PUSTAKA}

Alvira, Lidya. 2014. Faktor Risiko Hepatitis A di Kecamatan Bintan Timur Kabupaten Bintan Provinsi Kepulauan Riau. Bintan

Arbi, Sri Sutriani, dkk. Faktor yang Berhubungan Dengan Perilaku Pencegahan Hepatitis A pada Siswa SMA Negeri 2 Pangkajene. Makassar : Fakultas Kesehatan Masyarakat Universitas Hasanuddin

Dr. H. Masriadi, S.KM., S.Pd.I., S.Kg., M.Kes., M.H. 2017. Epidemiologi Penyakit Menular Ed. 1 Cet.2. Depok : PT Raja Grafindo Persada

drg. Oscar Primadi, M. 2014. Profil Kesehatan Republik Indonesia Tahun 2013. In Kementerian Kesehatan Republik Indonesia. https://doi.org/10.1088/0305-4470/14/8/037

Dinas Kesehatan Kabupaten Pacitan. 2019. Profil Kesehatan Kabupaten Pacitan Tahun 2019. Pacitan

Hastuti, Dwi, Suklan. 2012. Hubungan Pengetahuan, Sikap, dan Praktik Pencegahan Hepatitis A dengan Kejadian Hepatitis A pada Warga Kelurahan Bojongsari Lama Depok 2012. Jakarta : STIKes MH. Thamrin

Kementrian Kesehatan Republik Indonesia. 2018. Laporan Nasional Riset Kesehatan Dasar 2018. $1-582$.

Kemenkes RI. 2018. Peraturan Menteri Kesehatan Republik Indonesia Nomor 949/Menkes/Sk/Viii/2004 Tentang Pedoman Penyelenggaraan Sistem Kewaspadaan Dini Kejadian Luar Biasa (KLB). 1-26.

Notoatmodjo, Soekidjo. 2013. Promosi Kesehatan. Jakarta : Rineka Cipta

Notoatmodjo, S. 2007. Kesehatan Masyarakat IImu dan Seni. Jakarta: Rineka Cipta

Rahmah, S., \& Indriani, C. 2014. Hubungan Faktor Perilaku Dengan Kejadian Hepatitis A Di Kecamatan Depok Kabupaten Sleman. Media Kesehatan Masyarakat Indonesia : Universitas Gadjah Mada, 10(1), 16-20.

Ratih, Derma Kamsil. 2015. Hubungan Perilaku Masyarakat Dengan Kejadian Hepatitis A di Desa Koto Nan IV Kecamatan Ranah Pesisir Kabupaten Pesisir Selatan. Padang : Universitas Andalas

Sakti, A. P. 2012. Hubungan Pengetahuan, Sikap, dan Praktik Pencegahan Hepatitis A Dengan Kejadian Hepatitis A pada Siswa SMAN 4 Depok 2012. Fakultas Kesehatan Masyarakat Universitas Indonesia 